\title{
Influence Of Microfinance On Economic Empowerment Of Women
}

\section{Shalini $^{1 *}$, Prof. Bindu Arora ${ }^{2}$, Dr. Anil Dangwal ${ }^{3}$}

1. Shalini* (Research scholar), Department of Management Studies, Kanya Gurukul campus, Gurukula Kangri (Deemed to be University) Haridwar, Uttarakhand (India)

2. Dr. Bindu Arora (Professor), Department of Management Studies, Kanya Gurukul Campus, Gurukula Kangri (Deemed to be University) Haridwar, Uttarakhand (India)

3. Dr. Anil Dangwal (Assistant Professor), Faculty of Management Studies, Gurukula Kangri (Deemed to be University) Haridwar, Uttarakhand (India).

*Corresponding author: shaliniarya@live.in

\begin{abstract}
Women have competencies of changing the society along with the world. In developing countries, women are facing evil of gender discrimination. Men and women are not equally privileged but scenario is changing now because females are being empowered but still women are suffering from gender inequality problem. Women empowerment is need of hour for development of the world. The government took initiative in form of microfinance to carry forward women in life. So, it becomes necessary to analyse influence of microfinance on women empowerment. It is based on descriptive research design with using multistage sampling technique. The sample size is 400 rural women beneficiaries of Haryana and information is collected by pre-designed questionnaire through interview Data is conducted through SPSS. Regression and correlation analysis is used to examine data through SPSS. Microfinance measured through micro-credit and micro saving. Economic empowerment selected indicators are household income and household saving. The researchers found that there is positive impact of microfinance on economic empowerment of women. This study will be fruitful for the government, microfinance institutions and banks in policies making to empower women. This study could encourage women for savings and investing activities. It might inspire women to take part in microfinance schemes.
\end{abstract}

Keywords: Microfinance, economic, empowerment, women, household, saving, credit 


\section{INTRODUCTION}

Gender inequality is the leading challenge in the way of development of world especially in developing countries. Development is not possible without gender equality. Men and women have equal rights in constitution only, not in reality (Modi et al., 2014). Women are the vulnerable part of society. Scenario is changing in modern times but total change needed if we want to see our country in the list of developed countries. A country can't develop without development of women. So, gender discrimination evil can be abolished with empowering women. Empowerment of women is the need of hour for the growth country in positive direction. For empowerment of women, government has inaugurated several programs of microfinance. The government is spending huge fund on these program. The government is promoting microfinance through two models are followed Self-help group (SHG) model and Joint Liability group (JLG) model. Self-help group is an informal group of 10-20 members and they start saving and lending money to accomplish their requirements. The government lends money at lower rates to groups' members for investing in income generating activities. The government organises orientation training program and skill development program to train members through NGOs and banks. Second is Joint Liabilities Group model is called credit lending model. In this model, women come near to form group of 5-10 women for borrowing money. In this model women give guarantee of group. Obligation of group members will arise due to default instalment. Installments are paid weekly, fortnightly and monthly basis. Microfinance Institutions are following this model to empower women. Women should come forward to take fuller utilization of schemes.

\section{MICROFINANCE}

Dr. Muhammad Yunus is the father of modern microfinance concept. In 1976, he founded Grameen bank and started microcredit services to poor rural people without any security. Now, microfinance is used worldwide to empower women or poor. Microfinance is a type of financial service that included micro-credit, micro-saving, micro-insurance and training services without any indemnity. Reserve Bank of India identified microfinance as an instrument for economic development to achieve the goal of poverty eradication by providing financial and non-financial services of microfinance. In addition to, Schreiner (2000) defined microfinance as an authorised 
system to uplift poor with saving and lending services. Further, Annan (2005) called microfinance an idea to change lives.

\section{WOMEN EMPOWERMENT}

Women empowerment is a multi-dimensional process of encouraging economically, socially, politically and psychologically to women. Women must achieve honourable position in family as well as in society. Women empowerment is an initiative to facilitate women for raising voice against injustice and bring them into decision making process.

Economic empowerment is the key dimension of women empowerment. United States Women identified that investment in economic empowerment is the main way to abolished evil of gender discrimination and poverty. CARE international defined economic empowerment as process to increase their rights in financial resources and authority to take advantage for family, society and themselves.

\section{LITERATURE REVIEW}

Cheston and Khun (2002) exposed involvement of women increased in household decisionmaking because employment increased their contribution in household expenses. Further, Swain and Wallentin (2007) revealed that members of SHGs saved money more than non-members. Again in, Mohapatra and Sahoo (2009) identified positive impact of microfinance on income, employment, education and resources of member as compared to non-members. Whereas, Hussain (2012) found that BRAC diverted members to productive activities and increased their income and expenditure of family. The researcher also observed minor effect on saving but encouraging attitude towards saving. Further, Arora and Arora (2012) exposed that women became able to improve their earnings level. Also, Zoynul and Famida (2013) analysd impact of micro-credit on income and found microcredit assisted them employment and earned income. In addition to, Kavitha and Meenakshisundaram (2013) observed increased saving habit of women.

Again, Rahman, Moajjam, Ansari (2015) observed that microfinance helped women to bring positive change in domestic conditions. Further, Herath et al. (2015) revealed that microcredit increased member's level of income and decision to use fund. Whereas, Mahmood et al. (2016) found that women spend borrowed fund on income generating activities. Women expressed 
increment in household income, expenditure and standard of living after getting microfinance. In addition to, Akter and Pustika (2017) exposed that men and women have equal access of financial resources and women have more control over household income. Further, Nagaraja (2018) observed financial support of women in family earnings and national income. Whereas, Naiz and Iqbal (2019) observed that there was marginal expansion in income of beneficiaries. After them, Joshi (2019) found an enhancement in average household income of members after joining SHGs.

\section{RESEARCH METHODOLOGY}

It is based on descriptive research design with using multistage sampling technique. On first step Haryana state is selected on the basis of low sex ratio. On second step, two districts Gurugram and Nuh selected. Gurugram is district of lowest sex ratio and Nuh with highest sex ratio in Haryana. On third step, selected Patudi and Nuh block where maximum no. of SHGs to collect data of 400 from women members of SHGs. Processed data is collected from NRLM website, NABARD's report and published journals. Regression and correlation analysis is used to examine data through SPSS.

\section{OBJECTIVES OF THE STUDY}

1. To analyse the influence of micro-credit and micro-saving on household income.

2. To analyse the influence of microcredit and micro-saving on household saving.

3. To analyse the relationship among micro-credit, micro-saving and household income.

4. To analyse the relationship among micro-credit, micro-saving and household-saving.

\section{HYPOTHESES}

$\mathbf{H}_{01}$ : There is no significant impact of micro-credit and micro-saving on household income.

$\mathbf{H}_{02}$ : There is no significant impact of micro-credit and micro-saving on household saving.

$\mathbf{H}_{\mathbf{0 3}}$ : There is no relationship among micro-credit, micro-saving and household income.

$\mathbf{H}_{\mathbf{0 4}}$ : There is no relationship among micro-credit, micro-saving and household saving. 


\section{RESEARCH APPROACH}

The conceptual research suggests that the independent variable is microfinance and measured through micro-credit and micro-saving. The dependent variable is economic empowerment and selected indicators are household income and household saving.

\section{CONCEPTUAL FRAMEWORK}

Figure 1:

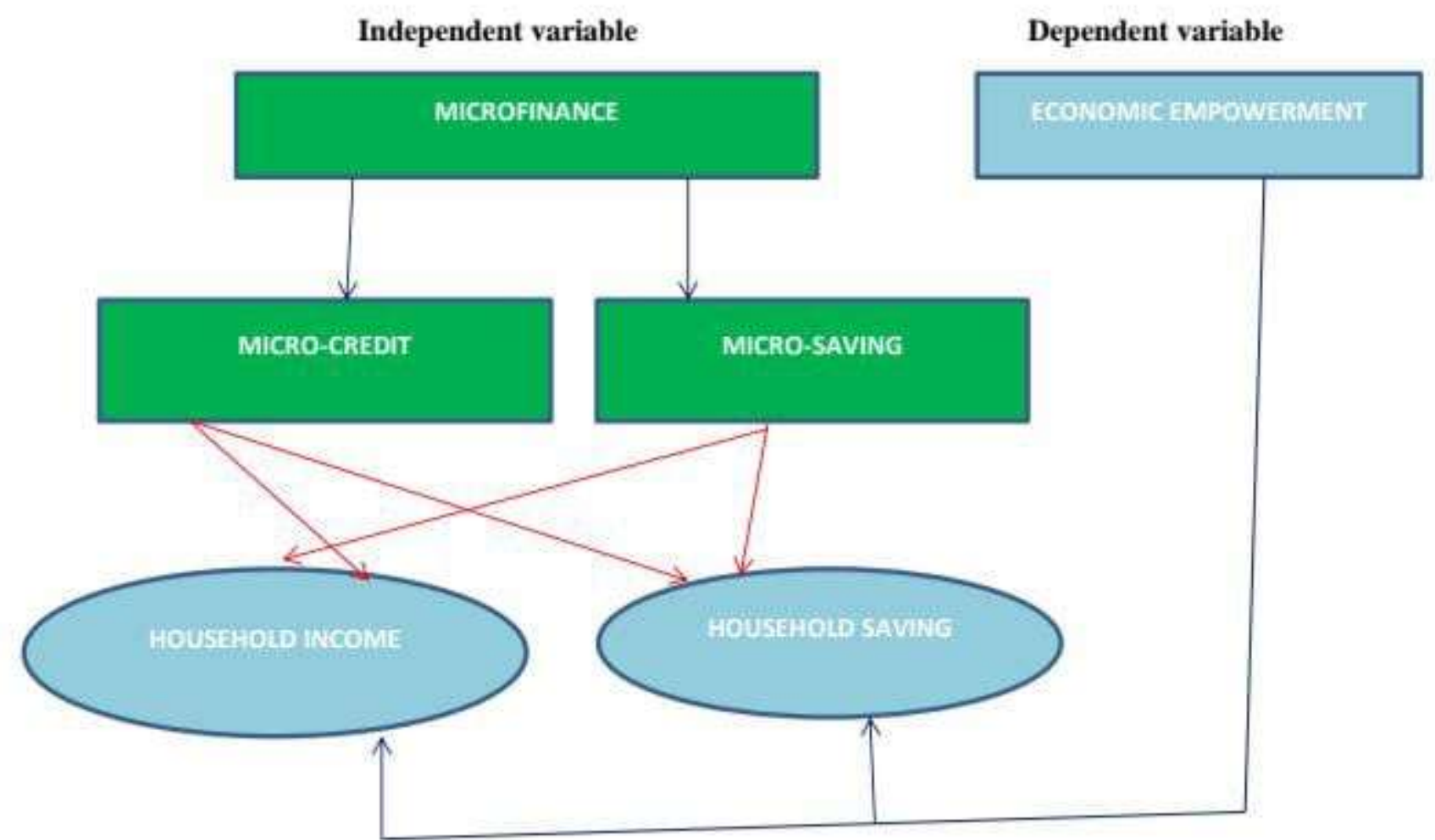




\section{ANALYSIS AND INTERPETATION}

Model - I: Dependent Variable - Average household income

Table 1: Correlations

\begin{tabular}{|l|l|r|r|r|}
\hline \multicolumn{2}{|c|}{} & $\begin{array}{c}\text { Micro credit } \\
\text { cycle }\end{array}$ & Micro Saving & $\begin{array}{c}\text { Average } \\
\text { Household } \\
\text { Income }\end{array}$ \\
\hline \multirow{2}{*}{ Micro credit cycle } & Pearson Correlation & 1 & $.784^{* *}$ & $.856^{* * *}$ \\
\cline { 2 - 5 } & Sig. (2-tailed) & & .000 & .000 \\
\hline \multirow{2}{*}{ Micro Saving } & Pearson Correlation & & 1 & $.798^{* * *}$ \\
\cline { 2 - 5 } & Sig. (2-tailed) & & & .000 \\
\hline Average Household & Pearson Correlation & & & .000 \\
\cline { 2 - 5 } & Sig. (2-tailed) & & & 1 \\
\hline
\end{tabular}

**. Correlation is significant at the 0.01 level (2-tailed).

Interpretation- Table-1, showing strong correlation among the Micro credit cycle, Micro saving and average household income.

Table 2: Result of Multiple Regression Analysis - Model I

\begin{tabular}{|l|l|}
\hline Y= Dependent variables & $\begin{array}{l}\text { Average Household } \\
\text { Income }\end{array}$ \\
\hline Intercepts & $\mathrm{B}=19.464$ \\
\cline { 2 - 2 } & $\mathrm{t}=4.360$ \\
\cline { 2 - 2 } & $\mathrm{P}=.000^{* * *}$ \\
\hline $\mathrm{X} 1=$ Micro Credit cycle & $\mathrm{B}=1.125$ \\
\cline { 2 - 2 } & $\mathrm{t}=2.65$ \\
\cline { 2 - 2 } & $\mathrm{P}=0.024^{* *}$ \\
\hline $\mathrm{X} 2=$ Micro Saving & $\mathrm{B}=0.86$ \\
\hline
\end{tabular}




\begin{tabular}{|l|l|}
\hline \multirow{5}{*}{} & $\mathrm{t}=2.21$ \\
\cline { 2 - 2 } & $\mathrm{P}=0.035$ \\
\cline { 2 - 2 } & $\mathrm{t}=3.656$ \\
\cline { 2 - 2 } & $\mathrm{P}=0.001 * * *$ \\
\hline F & $\mathrm{F}=7.91$ \\
\cline { 2 - 2 } & $\mathrm{P}=0.000^{* * *}$ \\
\hline Rdjusted R Square & $\mathbf{0 . 6 5 9}$ \\
\hline
\end{tabular}

$* \mathrm{P}<0.1 * * \mathrm{P}<0.05 * * * \mathrm{P}<0.01$

\section{Regression Equation}

The estimated regression equation 2 as follows:

$\mathrm{Y}=19.464+1.125 \mathrm{X}_{1}+0.86 \mathrm{X}_{2}$

Interpretation: Table 2 shows results of multiple regression analysis in which average household income is dependent variable. R Square is 0.659 which explains $65.95 \%$ variations in Average household income and regression model is fitting with observations.

Table 2 describes $\mathrm{p}$ values are 0.02 for $\mathrm{X} 1$ and 0.001 for $\mathrm{X} 2$ which is less than predicted value. It explains significant contribution of micro credit cycle and micro-saving in the model.

\section{Model - II: Dependent Variable - Household saving}

Table 3: Correlations

\begin{tabular}{|l|l|r|r|r|}
\hline \multicolumn{2}{|c|}{} & $\begin{array}{c}\text { Micro credit } \\
\text { cycle }\end{array}$ & Micro Saving & $\begin{array}{c}\text { Average } \\
\text { Household } \\
\text { Income }\end{array}$ \\
\hline \multirow{2}{*}{ Micro credit cycle } & Pearson Correlation & 1 & $.784^{* *}$ & $.784^{* * *}$ \\
\cline { 2 - 6 } & Sig. (2-tailed) & & .000 & .000 \\
\hline \multirow{2}{*}{ Micro Saving } & Pearson Correlation & & 1 & $.822^{* * *}$ \\
\cline { 2 - 6 } & Sig. (2-tailed) & & & .000 \\
\hline
\end{tabular}




\begin{tabular}{|l|l|l|l|r|}
\hline \multirow{2}{*}{ Household Saving } & Pearson Correlation & & & 1 \\
\cline { 2 - 5 } & Sig. (2-tailed) & & & .000 \\
\hline
\end{tabular}

** Correlation is significant at the 0.01 level (2-tailed).

Interpretation- Table-1, showing strong correlation among the Micro credit cycle, Micro saving and Household saving.

Table 4: Result of Multiple Regression Analysis - Model II

\begin{tabular}{|l|l|}
\hline Y= Dependent variables & $\begin{array}{l}\text { Average Household } \\
\text { Saving }\end{array}$ \\
\hline Intercepts & $\mathrm{B}=6.52$ \\
\cline { 2 - 2 } & $\mathrm{t}=4.21$ \\
\cline { 2 - 2 } & $\mathrm{P}=.000^{* * *}$ \\
\hline $\mathrm{X} 1=$ Micro Credit cycle & $\mathrm{B}=0.46$ \\
\cline { 2 - 2 } & $\mathrm{t}=2.65$ \\
\cline { 2 - 2 } & $\mathrm{P}=0.018^{* *}$ \\
\hline $\mathrm{X} 2=$ Micro Saving & $\mathrm{B}=0.98$ \\
\cline { 2 - 3 } & $\mathrm{t}=2.25$ \\
\cline { 2 - 2 } & $\mathrm{P}=0.025^{* *}$ \\
\hline $\mathrm{F}$ & $\mathrm{F}=7.91$ \\
\cline { 2 - 2 } & $\mathrm{P}=0.000^{* * *}$ \\
\hline R Square & 0.602 \\
\hline Adjusted R Square & 0.599 \\
\hline
\end{tabular}

$* \mathrm{P}<0.1 * * \mathrm{P}<0.05 * * * \mathrm{P}<0.01$

\section{Regression Equation}

The estimated regression equation 2 as follows:

$\mathrm{Y}=6.52+0.46 \mathrm{X}_{1}+0.98 \mathrm{X}_{2}$

Table 4 shows results of multiple regression analysis in which household saving is dependent variable. R Square is 0.602 which explains $60.20 \%$ variations in household saving and regression model is fitting with observations. 
Table 4 describes $\mathrm{p}$ values are 0.018 for $\mathrm{X} 1$ and 0.025 for $\mathrm{X} 2$ which is less than predicted value. It explains significant contribution of microcredit cycle and micro-saving in the model.

\section{CONCLUSION AND FUTURE RESEARCH}

Microfinance is an effective tool for empowering women because microfinance provides financial assistance to poor women. The researchers found strong correlation among the microcredit cycle, micro-saving and average household income. It is also found that there is strong relationship among microcredit cycle, micro-saving and household saving. It is also revealed from findings that microfinance (microcredit cycle and micro-saving) has positive influence on indicators of economic empowerment (household saving and household income). There are some supporting literatures which reveal that there is positive impact of microfinance on economic empowerment of women (Swain and Wallentin, 2007; Mohapatra and Sahoo, 2009; Kavitha and Meenakshisundaram, 2013).

This study will be fruitful for the government, microfinance institutions and banks in policies making to empower women. This study could encourage women for savings and investing activities. It might inspire women to take part in microfinance schemes. The main limitation of the study is that the sample is taken from Haryana state only therefore care is required when generalizing the results. Future research can be implemented with taking data from selected states of India. 


\section{REFERENCING}

Akter, S., Rutsaert, P., Luis, J., Htwe, N.M., San, S.S., Raharjo, B. and Pustika, A., 2017. Women's empowerment and gender equity in agriculture: A different perspective from Southeast Asia. Food Policy, 69, pp. 270-279.

Arora, S. and Arora, S., 2012. Role of Micro-financing in women empowerment: An empirical study of urban Punjab. Pacific Business Review International, 5(1), pp. 46-60.

Cheston, S. and Kuhn, L., 2002. Empowering women through microfinance. Draft, Opportunity International, 64, pp. 1-64

Herath, H.M.W.A., Guneratne, L.H.P. and Sanderatne, N., 2015. Impact of microfinance on women's empowerment: a case study on two microfinance institutions in Sri Lanka. Sri Lanka Journal of Social Sciences, 38(1), pp. 51-61.

Herath, H.M.W.A., Guneratne, L.H.P. and Sanderatne, N., 2015. Impact of microfinance on women's empowerment: a case study on two microfinance institutions in Sri Lanka. Sri Lanka Journal of Social Sciences, 38(1), pp. 51-61.

Hossain, M. K., 2012. Measuring the impact of BRAC microfinance operations: A case study of a village. International Business Research, 5(4), pp. 112-123.

Joshi, G., 2019. An analysis of women's self-help groups' involvement in microfinance program in India. Rajagiri Management Journal, 13(2), pp. 2-11.

Kavitha, L. and Meenakshisundaram, K.S., 2013. Role of microfinance on women empowerment especially in the rural areas. AMET International Journal of Management, pp. 67-75.

Mahmood, T., Arby, M. F., Hussain, T. and Sattar, A., 2016. Impact of microfinance on income generation and living standards. Pakistan Economic and Social Review, 54(1), pp. 73-80. 
Mohapatra, S. and Sahoo, B. K., 2016. Determinants of participation in self-help-groups (SHG) and its impact on women empowerment. Indian Growth and Development Review, 9(1), pp. 5378.

Nagaraja, K., 2017. Empowerment of women through higher education. International Journal of Current Research, 10(2), pp. 66113-66115.

Niaz, M. U. and Iqbal, M., 2019. Effect of microfinance on women empowerment: A case study of Pakistan. Paradigms, 13(1), pp. 52-59.

Modi, A., Patel, K. J. and Patel, K., 2014. Impact of microfinance services on rural women empowerment: An empirical study. IOSR Journal of Business and Management, 16(11), pp. 6875.

Schreiner, M., 2001. Informal finance and the design of microfinance. Development in Practice, 11(5), pp. 637-640.

Rehman, H., Moazzam, D.A. and Ansari, N., 2020. Role of microfinance institutions in women empowerment: A case study of Akhuwat, Pakistan. South Asian Studies, 30(1), pp.107-125

Silva, I. D., 2012. Evaluating the impact of microfinance on savings and income in Sri Lanka: quasi-experimental approach using propensity score matching. Margin: The Journal of Applied Economic Research, 6(1), pp.47-74.

Zoynul, A. M. and Fahmida, M., 2013. Women empowerment through micro credit: A case study of Dinajpur, Bangladesh. Studies in Business \& Economics, 8(2), pp.5-19.

\section{Webpages}

http://www.care-international.org

http://www.nabard.org

http://nrlm.gov.in

http://ada-microfinance.org 